Article

\title{
Savings of Small Farms: Their Magnitude, Determinants and Role in Sustainable Development. Example of Poland
}

\author{
Barbara Wieliczko ${ }^{1}$, Agnieszka Kurdyś-Kujawska ${ }^{2, *}$ and Agnieszka Sompolska-Rzechuła ${ }^{3} \mathbb{C}$ \\ 1 Institute of Agricultural and Food Economics-National Research Institute, Świętokrzyska 20, \\ 00-002 Warszawa, Poland; barbara.wieliczko@ierigz.waw.pl \\ 2 Department of Finance, Faculty of Economics, Koszalin University of Technology, Kwiatkowskiego 6e, \\ 75-343 Koszalin, Poland \\ 3 Department of Applied Mathematics in Economics, Faculty of Economics, West Pomerania University of \\ Technology Szczecin, Janickiego 31,71-270 Szczecin, Poland; asompolska@zut.edu.pl \\ * Correspondence: agnieszka.kurdys-kujawska@tu.koszalin.pl; Tel.: +48-94-3439-160
}

Received: 9 October 2020; Accepted: 2 November 2020; Published: 4 November 2020

\begin{abstract}
Savings are a catalyst for capital creation and are the driving force behind economic growth and development. The degree of development achieved by farms will largely depend on their ability to accumulate income and their way of spending. The aim of the article is to determine the savings-generating potential of small farms in Poland and the impact of savings on their sustainable development. In this article, firstly, the literature on savings in small farms and their role in sustainable development is synthesized. Secondly, presents empirical research that was conducted considering the economic and social characteristics of 1485 small farms to help understand saving behaviors in the chosen context. The research material consisted of data on entities participating in the Polish Farm Accountancy Data Network (FADN) in 2017. The factors influencing the generation of savings were identified using the logit regression model. The results of the research indicate great diversity in the scale of savings generated by small farms in Poland. Moreover, the study showed that 4 out of 21 variables characterizing small farms were significant, with a good fit of the model as evidenced by the model quality assessment measures used (coefficient $R^{2}$ count and ROC curve). It was found that two variables, namely area of farmland and gross value added, each had a statistically significant positive influence on the probability of generating higher savings by small farms in Poland. On the other hand, the possession of liabilities and gross investment each had a statistically significant negative influence on the accumulation of higher savings. The research reveals some limitations that may hinder the mobilization of savings by small farms and thus affect their sustainable development. Therefore, as recommendations, we present measures that can increase savings by small farms in Poland.
\end{abstract}

Keywords: savings; small farms; sustainable development

\section{Introduction}

Sustainable farm development is a process of structural transformation, changing the relations of production factors within a farm, the structure of economic activity, or the nature of its relations with the market towards achieving a new point of balance at a higher level of economic efficiency in accordance with external conditions, including the need to protect natural resources [1]. It depends largely on the capital accumulated in the farm and the use of these resources in the form of savings for further improvement of the farm's performance. Saving is undeniably considered a strategic variable in the theory of economic growth, determining both individual and national well-being [2]. 
The level of savings of farms, especially small ones, is low, which limits their development possibilities. Poor capacity to save is a result of low real income achieved by these individuals. In recent decades, the income problems of small farms have become an important problem in many countries in Europe and worldwide. Looking at the current economic situation in the agricultural sector, which is dominated by global markets, farm specialization, growth in scale, and decoupling between rural communities and agricultural enterprises, small farms may seem inefficient and irrelevant to modern agriculture [3,4]. Many proponents emphasize the importance of "smallholder farming" or "family farming", often claiming that smallholders or family farms are responsible for a significant proportion of global food production $[5,6]$. However, importantly, these farms not only carry out agricultural activities using different production methods, but also provide numerous public goods and contribute to maintaining the diversity of the landscape. Their existence helps to maintain the population of rural areas. From a social point of view, they importantly favor cultivating folk traditions and customs. The functioning of small farms is connected with the life of numerous families, often living in the countryside for many generations [6-17]. Small farms, therefore, play a significant role in the process of sustainable agricultural development in three key aspects: economic, social, and environmental [18-20]. Efficient organizational structures and effective management, durable income stabilization and growth systems, and access to (micro)loans will increase the capacity and resilience of small farmers, thus driving sustainable development. According to Nib et al. [21], capital accumulation is the main condition for farm development, and if the amount of savings is insufficient to meet income requirements, serious bottlenecks in the process of capital formulation and development efforts are likely to emerge. This problem becomes particularly important for small farms.

In the literature, the definition of a small farm usually refers to a farmer with a small area of land, with limited resources, direct involvement of the family labor force in farming, poor market connection, and low level of technology applied in the production process [22-26]. In general, small farms make up about $80 \%$ of all farms in the EU, covering $25 \%$ of the total utilized agricultural area $[27,28]$. In Poland, small farms account for $76 \%$ of all farms, of which more than half are farms with an area below 5 ha. A similar area structure of agricultural holdings to Poland is characteristic of such European countries as Austria, Estonia, Spain, Lithuania, Latvia, Slovenia, and Italy [29]. Thus, small farms are an important element of European agriculture. These farms, most of which are family farms, face major challenges due to current trends such as migration to cities, aging population, and climate change. As savings are crucial for the welfare, sustainability, increased competitiveness, and development of small farms [30-34], an understanding of what makes them more diverse and higher can help to identify appropriate support schemes set up by all public and private institutions for which sustainable agriculture and rural development are important. The aim of this research was to determine the savings-generating potential of small farms in Poland and the impact of savings on their sustainable development. This study serves as an attempt to answer two questions: (1) What is the size of savings in small farms and what determines them? (2) Are the savings of small farms sufficient for theirparticipation in the process of sustainable development?

Saving in general can be related to the part of the income that is not immediately consumed, but is stored for future investments, consumption, or unforeseen expenses [35]. The capacity for generating savings is therefore an important part of the decision-making process in farms. Theamount of savings determines several decisions related to the activity conducted and the farmer's household. According to Gokhale [36], savings have two basic functions. Firstly, savings provide economic security. Savings are a safety buffer. By transferring resources from the present to the future through savings, people are prepared for unexpected and irregular financial conditions. Secondly, savings lead to an accumulation of wealth that enables people to improve their living standards and respond to new opportunities.

Savings and their efficient transformation into effective investments are a factor in building the economic capacity of farms and accelerating their sustainable development [37]. Savings allow farm resources to be increased both in terms of quantity and quality, as well as ensuring the increase of 
efficiency in the use of physical and human capital [38]. The ability to accumulate savings and their level determines farmers' investment decisions related to farm size and level of innovation [39-41]. Farmers with the ability to accumulate income are more likely to implement and use the latest technologies in the production and apply digital solutions, facilitate the conditions for creating high-quality products, strengthen the ability to adapt to climate change, and gradually improve soil and land quality. Moreover, savings, especially in small farms, are part of a risk management strategy that consists of self-financing losses resulting from various risks [35,42-45]. Income accumulation contributes to strengthening the resilience of farms to threats, i.e., reducing their vulnerability in relation to extreme climatic events and other economic, social, and environmental shocks. However, in addition to being a catalyst for capital creation [46], savings are also important for smoothing future consumption in the face of variable and unpredictable agricultural income. This is especially important now, when the world is fighting the COVID-19 pandemic and the economy and livelihoods are disrupted.

According to previous literature, savings of small farms and the level of their mobilization are conditioned by several social, economic, and institutional factors. These include age, gender, and level of education of a farm manager; agricultural experience; number of people in a family; size of an agricultural holding; land ownership; type of production; income from agricultural activity; nonagricultural income; costs of agricultural activity; debt; size of production assets; and aversion to risk [47-65]. The income is considered the most important factor determining the savings of farms. Different empirical studies based on diverse methodologies carried out in various parts of the world showed a positive relationship between income and savings. This is in line with the Keynesian theory of consumption, which postulates a positive relationship between income and savings, where income levels have a direct impact on savings. Nayak [62] proved that the number of people in a family and their ability to work has an impact on generating surplus financial resources. Farms with more active members involved in business have relatively higher savings than other farms. Ahmad and Asghar [63] indicated that a larger number of family members is related to a lower savings. Girma et al. [64] pointed out that the diversification into nonagricultural activities increases the savings of small farms. Gedela [65], in her study, showed a positive relationship between the age of the head of the farm and savings. The increase in age resulted in an increase in savings, but only until a certain point, after which savings fell. This is consistent with the life cycle theory that explains the importance of age in saving. This theory shows that people are likely to earn and save more at working age until they reach their maximum retirement age; i.e., savings are likely to fall when they reach retirement age [43]. Kolandavel and Nigatu [60] proved that land ownership affects the level of savings generated. The amount of land owned affects income and income affects savings. Farmers with larger acreage not only produce for their own needs but also provide part of the yields to the market. Moreover, a larger area helps farmers to benefit from economies of scale and higher production. Obayelu [50] showed that farms with owned land were able to save relatively more than others. Land owned by a farmer can increase savings by generating additional income in the form of rent. The land owned by a farmer is also collateral for loans granted to farmers. These, in turn, can be effectively used to improve land productivity and increase income levels, resulting in higher savings. Kolandavel and Nigatu [60] also showed a statistically significant positive relationship between the level of savings and the debt of small farms. The reason for this relationship may be that a higher amount of savings naturally leads to a higher amount of debt. Another reason is that higher indebtedness allows farmers to earn more, and increased income can be converted into savings. Odoh et al. [49] showed that the variability of farmers' savings pattern was caused by their level of education and farming experience. As farmers gain higher education, they are more likely to adopt higher saving patterns. The relationship with agricultural experience is similar: more experience gained by the farmer over the years translates to higher savings. As Adeyemo and Bamire [48] proved, with increasing agricultural experience, farmers are more efficient in their farming activities, thus generating more income and increasing their savings. The level of savings generated by small farms is a result of both economic and 
social factors. It is difficult to grasp the role of a single factor in research on the factors determining the savings of small farms, as these factors are interrelated and influence the level of savings in a synergic way. The complexity and multifaceted determinants influencing the level of generated savings require the judgment of the accuracy of the identification of individual factors. Endogenous factors related to the social and economic potential of farms affect the level of savings, which determines the processes of change in farms towards sustainable development. Even under very favorable external circumstances, it is difficult to imagine that these changes will be implemented on farms that do not have the capacity to generate savings. It should be assumed that farms with a higher ability to self-finance and generate savings will achieve the objectives of economic, social, and environmental sustainability faster and easier.

The above discussion highlights several factors that have been identified in several previous studies as important determinants of savings. However, the endogenous factors observed are contextual in nature and are not always similar. There is a lack of studies in which, apart from social and economic factors (in particular, income, farm size, or production volume), factors reflecting the technical and economic efficiency of the farm are used to explain the saving behavior of small farms. Moreover, most of the studies to date are of a fragmentary nature. They were conducted mainly on a regional rather than national level. Most of them concerned regions from developing countries. This issue is less often considered in developed countries. Therefore, this study aims to fill this gap and contribute to the knowledge of the savings-generating potential of small farms.

\section{Materials and Methods}

\subsection{Materials}

The study is based on the data set from the Polish Farm Accountancy Data Collection and Use System (FADN). The study covered 1485 agricultural holdings, each with an agricultural area of up to 10 ha and an economic size no larger than EUR 8000. According to the FADN, these holdings are classified as very small and small. The analyzed entities accounted for $12.27 \%$ of all agricultural holdings participating in the FADN in Poland in 2017.

Among the analyzed group of small farms, $97 \%$ declared the ability to self-finance their activities and create savings within the operating activity. The average farm area in the analyzed group was 7.22 ha. Most of the small farmers carried out multidirectional production (30.91\%). A high percentage of the analyzed small farms were also farms specializing in field crops (21.01\%) and horticultural crops $(18.25 \%)$. Only a few small farms conducted animal production. The reason for this situation may be the extensive and nonfunctional EU administrative and veterinary regulations, especially concerning the breeding of livestock and local trade in animal products. In practice, direct sale of agri-food products from farms, especially of animal origin, is blocked [66]. The increase in the value of goods produced in small farms, the so-called gross value added, was PLN 32,660 (EUR 8166). The gross value added is influenced by, among other factors, the costs related to conducted agricultural activity. In the agricultural holdings under analysis, costs related to plant and/or animal production in half and more of small agricultural holdings amounted to PLN 16,080 (EUR 4022). On the other hand, costs related to the involvement of foreign production factors (labor, changes, and capital) in the production process were small, constituting PLN 500 (EUR 125) in most small agricultural holdings. Small farms reached PLN 2030 (EUR 500) in profit per hectare of agricultural land. Income earned from agricultural production in these farms constituted $31.31 \%$ of the total income. The effectiveness of the use of total assets stood at the level of $15 \%$. This means that the assets owned by these farms made it possible to generate a profit of PLN 0.0015. It also proves the low efficiency of property resources management related to maintaining redundant property assets or low level of their use. In most small farms, the value of production exceeded the costs of production. The production profitability index in more than one-half of small farms amounted to $114 \%$. The profitability of production of small farms was low. This is related to the small scale of production, which does not allow for the accumulation of financial 
resources for the investment and technological development of farms, which may result in the low profitability of production [67]. The type of production or the amount of costs incurred in connection with the conducted activity [68-71] is also important. Labor productivity per full-time employee was PLN 35,190 (EUR 8875). The average age of managers of small farms was 47 years. This indicates that small farmers in the surveyed area were mostly of middle age and were still economically active. This has an impact on agricultural production due to the ability of these people to cope with changes in agricultural activity. The analyzed group of small farmers was characterized by small differences in terms of age (coefficient of variation: 27.19\%). Experience in agriculture is also related to age, which is used as a measure of management capacity. More experienced the farmers are more likely to make effective decisions which will increase production and income. Most of the small farmers had secondary education ( $43.30 \%$ ) or basic vocational education (38.59\%). The least numerous group consisted of farmers with primary education (4.65\%). Higher education was declared by $13.36 \%$ of small farmers. As many as $15.21 \%$ of small farmers had liabilities to financial institutions. Investments consisting in the purchase of fixed assets and the enlargement of the basic stock were implemented in $38.32 \%$ of small farms.

\subsection{Method}

In this study, a logit regression model was used to determine the factors influencing the capacity of small farms to generate savings. The logit model made it possible to describe the relationship between the dichotomous qualitative variable "having savings" $(Y)$ and a set of independent variables $\left(X_{1}, \ldots, X_{k}\right)$. In linear regression models, a linear relationship is assumed between the dependent variable $(Y)$ and the explanatory variable $(X)$. The dependent variable is a continuous type. However, in the case of logistic regression, it is assumed that the dependent variable is dichotomous or binary, i.e., $Y_{i}=0$ or 1 for all $i=1, \ldots, n$. The regression model using the logistic function has the following form:

$$
p_{i}=\frac{\exp \left(\beta_{0}+\beta_{1} X_{i}\right)}{1+\exp \left(\beta_{0}+\beta_{1} X_{i}\right)}
$$

where $\beta_{0}$ and $\beta_{1}$ are model parameters; $X_{i}$ are independent variables that can be both qualitative and quantitative; and $p_{i}$ is the probability that $Y_{i}=1$.

After linearization of the equation, we obtain [72]

$$
\frac{p_{i}}{1-p_{i}}=\exp \left(\beta_{0}+\beta_{1} X_{i}\right)
$$

In this case $\frac{p_{i}}{1-p_{i}}$ is called odds, and the log odds function is called logit.

The form of the logit-based model is as follows:

$$
p_{i}^{\prime}=\ln \left(\frac{p_{i}}{1-p_{i}}\right)=\beta_{0}+\beta_{1} X_{i}
$$

Odds are defined as the ratio of the likelihood of an event of occurring to the probability of an event not occurring. Since the logistic function is nonlinear, the direction coefficient $\beta_{i}$ represents the change in logit caused by the change of $X$ by one unit. In the context of odds, the interpretation of the directional coefficient is as follows: for $X$ variable having a continuous value, $\exp \left(\beta_{i}\right)$ is an increase in odds that $Y=1$ for each unit of growth of $X$ variable; for $X$ variable having the dichotomous value, $\exp \left(\beta_{i}\right)$ is an increase in the odds that $Y=1$, when $X=1$ in relation to the situation when $X=0$. The quality assessment of the model was based on the value of the coefficient $R^{2}$ count and the Receiver Operating Characteristic Curves (ROC curve) (see [73]). 


\subsection{Data}

The variables adopted in the model were quantitative and qualitative. The selection of variables was based on the available database and analysis of existing research in the field of generating savings by farms and on the analysis of correlations between variables. A set of explanatory variables was used in the model, and level of savings $Y$ ( 0 -savings below the median; 1 -savings above the median) was assumed to be the dependent variable. The distribution of the examined variables was asymmetric; therefore, their values were categorized in relation to the median, creating two categories of values: values smaller or equal to the median and values above the median. There were 21 explanatory variables used in the model, and they referred to the socioeconomic characteristics of the farmer and the farm (Table 1).

Table 1. Set of variables applied in the study.

\begin{tabular}{|c|c|}
\hline Variables & Category \\
\hline$X_{1}$ & $\begin{array}{l}\text { production type: } \\
\text { fieldcrops (yes-1; no-0) }\end{array}$ \\
\hline$X_{2}$ & $\begin{array}{l}\text { production type: } \\
\text { horticulture and permanent crops (yes- } 1 \text {; no- }-0)\end{array}$ \\
\hline$X_{3}$ & $\begin{array}{l}\text { production type: } \\
\text { animal production (yes-1; no-0) }\end{array}$ \\
\hline$X_{4}$ & $\begin{array}{l}\text { production type: } \\
\text { mixed (yes-1; no-0) }\end{array}$ \\
\hline$X_{5}$ & utilized agricultural area (ha) \\
\hline$X_{6}$ & direct costs (PLN`000) \\
\hline$X_{7}$ & general costs(PLN`000) \\
\hline$X_{8}$ & costs of external factors (PLN) \\
\hline$X_{9}$ & rural development support (PLN) \\
\hline$X_{10}$ & payments to operational activity (PLN) \\
\hline$X_{11}$ & total liabilities (yes- 1 ; no-0) \\
\hline$X_{12}$ & gross investment (PLN) \\
\hline$X_{13}$ & gross value added (PLN ‘000) \\
\hline$X_{14}$ & farmer's age (years) \\
\hline$X_{15}$ & $\begin{array}{c}\text { farmer's education level: } \\
\text { 1-primary education } \\
\text { 2-nonagricultural basic vocational education } \\
\text { 3-agricultural basic vocational education } \\
\text { 4-nonagricultural secondary education } \\
\text { 5-agricultural secondary education } \\
\text { 6-nonagricultural tertiary education } \\
\text { 7-agricultural tertiary education }\end{array}$ \\
\hline$X_{16}$ & land income generation rate (PLN ‘000/ha) \\
\hline$X_{17}$ & production income generation rate $(\%)$ \\
\hline$X_{18}$ & land productivity rate (PLN ‘000/ha) \\
\hline$X_{19}$ & labor productivity rate (PLN/AWU) \\
\hline$X_{20}$ & profitability of production (\%) \\
\hline$X_{21}$ & return on assets (\%) \\
\hline
\end{tabular}




\section{Results and Discussion}

\subsection{Magnitude Savings of Small Farms}

The amount of savings of small farms was determined by several factors of both social and economic nature. Farmers from farms with an area of up to 5 ha of farmland were able to mobilize higher savings. In this group, more than one-half of small farmers achieved savings of PLN 38,922 (EUR 9730). This group was characterized by remarkably high diversity in terms of the amount of savings generated (coefficient of variation: $276 \%$ ). On the other hand, in farms with an area of 5-10 ha of agricultural land, more than one-half of farmers declared the amount of accumulated savings to be at the level of PLN 23,895 (EUR 5973). These farms, similar to farms with an area of up to 5 ha of farmland, were characterized by great diversity in the amount of generated savings (coefficient of variation: $177 \%)$.

The largest group of the analyzed farms were entities diversifying crops (30.91\%). Maintaining crop diversity in small farms is usually associated with strategies for dealing with risk [74-78], optimizing production [79], providing trade opportunities in many local markets [76], improving food security $[80,81]$, and reducing vulnerability to market and climate variability $[76,82]$.

Small farmers, like others, makethe production decisions that will provide them with the greatest opportunities for income growth, survival, and development. The highest level of savings was generated by farmers from holdings specializing in horticulture. In more than one-half of these farms, the level of savings was PLN 61,131 (EUR 15,282). Farms specializing in the breeding of grain-eating animals were characterized by a level of savings like that of horticultural farms (PLN 58,266/EUR 14,566). The lowest generation of savings was recorded in small farms with diverseproduction (PLN 16,730/EUR 4182). This may result from the fact that the specificity of mixed production forces farmers to invest in various assets necessary for production. Using their own resources, they purchase seed or plant protection products in small quantities, sometimes paying more than farmers from farms with a larger production scale. They also need diversified machinery and equipment, the purchase, modernization, or maintenance of which is covered by the savings generated. A low level of savings (PLN 17,791/EUR 4447) was also generated by farms specializing in breeding animals fed in the grazing system (without dairy cows). In dairy farms, the level of savings in more than one-half of small farms oscillated at the level of PLN 28,671/EUR 7167, while in farms specializing in field crops it amounted to PLN 25,881/EUR 6470.

In more than one-half of the analyzed small farms, the farm managers were 50 years old or older. In the group of the youngest farmers, most of them generated savings of less than PLN 25,849 (EUR 6,462); a similar trend was observed in farms managed by farmers over 61. Higher savings were generated in farms managed by farmers aged 30 to 60 (Table 2). The low level of savings generated in the group of the youngest farmers may result from the fact that these are farmers who have recently taken over the farms or have just started to see their future in agriculture and started to accumulate their own life capital. It should be expected that their profitability will increase over the next few years, which will translate into higher savings. The introduction of subsidies for small farms is intended to help achieve such results. The problem of low savings in this group of farms should also be seen in the specificity of farm succession in Poland. Farmers who acquired pension rights or wanted to take advantage of early retirement gave the farms to their children who work outside agriculture. Formally, they are the owners of these agricultural holdings, but they have no influence on the decisions made on these farms in terms of production or investment activities generating higher income. On the other hand, farmers between 31 and 60 years of age, together with the acquired experience related to the conducted agricultural production, make more rational decisions in terms of production or investment. A higher level of savings in this group may result from a greater awareness of the threats connected with conducting agricultural production. For small farms, the use of other methods of risk management, including insurance, is not beneficial, mainly from the point of view of costs they must bear in connection with the transfer of risk to a specialized insurance institution. 
A higher level of savings in this age group may also result from obligations related to the education of children [83]. It may also be thought that this group of small farmers has mobilized savings to make future investments. Farmers over 61 years of age mostly generated lower savings. Xiao and Fan [84] proved that older people save less for investment but are more likely to save for retirement. At different stages of the life cycle, farmers may have different saving needs, so the motives for saving and the level of saving may vary. The results obtained are in line with the anticipated life cycle hypothesis, which predicts a high proportion of savers in the active age range of 30-65 years [85].

Table 2. Age of the farmer and the level of savings generated by small farms in Poland.

\begin{tabular}{cccc}
\hline \multirow{2}{*}{ Level of Savings (PLN) } & \multicolumn{3}{c}{ Age (Years) } \\
\cline { 2 - 4 } & Up to 30 & $\mathbf{3 1 - 6 0}$ & $\mathbf{6 1}$ and More \\
\hline Below the median * & $53.77 \%$ & $48.80 \%$ & $56.40 \%$ \\
Above the median * & $46.23 \%$ & $51.20 \%$ & $43.60 \%$ \\
\hline Note. * median value PLN 25,849 (EUR 6462). Source: Author's own analysis based on study material.
\end{tabular}

Having higher savings was characteristic for farmers with at least secondary education. Small farmers with secondary or tertiary education more often declared savings above PLN 25,849 (EUR 6,462) (Table 3). Higher education may foster the growth of economic awareness of small farmers, understanding of risk and the need to accumulate capital for future investments, and thus influence decisions to postpone consumption. Similar conclusions were reached by Girma et al. [64] and Lidi et al. [86], among others, who demonstrated that savings increase as farmers' education levels increase. This is theoretically justified by the fact that education can raise awareness about the mobilization of savings.

Table 3. Level of education of the farmer and the level of savings generated by small farms in Poland.

\begin{tabular}{ccccc}
\hline \multirow{2}{*}{ Level of Savings (PLN) } & \multicolumn{4}{c}{ Education Level } \\
\cline { 2 - 5 } & Primary & Basic Vocational & Secondary & Tertiary \\
\hline Below the median * & $59.42 \%$ & $52.53 \%$ & $49.46 \%$ & $41.50 \%$ \\
Above the median * & $40.58 \%$ & $47.47 \%$ & $50.54 \%$ & $58.50 \%$ \\
\hline
\end{tabular}

Note: * Median value PLN 25,849 (EUR 6462). Source: Authors' own analysis based on study material.

The generation of savings by small farms is also made possible by subsidizing agriculture and rural areas. Small farmers can benefit from public funds spent under the Common Agricultural Policy. On the one hand, there are direct payments, which, as a form of social protection, are often considered an important means of improving agricultural productivity in low- and middle-income countries [87].On the other hand, support under the Rural Development Programmes is aimed at restructuring agricultural holdings; increasing competitiveness; improving human capital, innovation, and provision of basic services in rural areas and related infrastructure; and improving the quality of agricultural products, support for sustainable use of agricultural land, diversification of the rural economy, compensation of income losses, and support for environmental improvement [88-90]. Studies carried out by Ciaian et al. [91] show that in terms of farm income and the possibility to mobilize higher savings, the most transparently effective instrument of the CAP appears to be the RDP, followed by the Single Payment Scheme. In the analyzed group of small farms, the annual income from direct payments increased in more than one-half of farms by PLN 268 (EUR 67). Such an increase in income will not significantly affect the increase in the level of generated savings, and thus it will not change investment opportunities in these farms. The research has also shown that in the analyzed group of small agricultural holdings declaring the creation of savings within the framework of operating activity, more than one-half $(53.89 \%)$ benefit from subsidies for rural development. The average value of public support was PLN 1535 (EUR 383). In more than one-half of small agricultural holdings, the value of subsidies for rural development amounted to PLN 614 (EUR 153). Over $60 \%$ of small farms benefited from rural development subsidies. This means that the lower 
level of savings from operating activities somehow forces them to undertake activities aimed at multifunctionality and thus improve their profitability and create nonagricultural jobs. Small farmers who achieved a higher level of savings from their operating activities more often (52.56\%) indicated that they did not benefit from rural development subsidies.

The level of savings generated is thought to have an impact on the possibility of using external sources of financing. This is confirmed by the results of the conducted research. In the group of small owners of agricultural holdings declaring the use of external sources of financing, over $72 \%$ indicate having savings at the level above PLN 25,849 (EUR 6462) (Table 4).

Table 4. Liabilities and the level of savings generated by small farms in Poland.

\begin{tabular}{ccc}
\hline \multirow{2}{*}{ Level of Savings (PLN) } & \multicolumn{2}{c}{ Liabilities } \\
\cline { 2 - 3 } & Yes & No \\
\hline Below the median * & $27.88 \%$ & $45.99 \%$ \\
Above the median * & $72.12 \%$ & $54.01 \%$ \\
\hline
\end{tabular}

Note: * Median value PLN 25,849 (EUR 6462). Source: Authors' own analysis based on study material.

In more than one-half of small farms, the gross investment value amounted to PLN 642 (EUR 160). Investments related to the purchase and production of fixed assets and the change in the value of the basic herd were more often implemented in agricultural holdings which generated a higher level of savings (Table 5).

Table 5. Gross investments and the level of generated savings of small agricultural holdings in Poland.

\begin{tabular}{ccc}
\hline \multirow{2}{*}{ Level of Savings (PLN) } & \multicolumn{2}{c}{ Gross Investment } \\
\cline { 2 - 3 } & Yes & No \\
\hline Below the median * & $47.28 \%$ & $51.75 \%$ \\
Above the median * & $52.72 \%$ & $48.25 \%$ \\
\hline
\end{tabular}

Note: * Median value PLN 25,849 (EUR 6462). Source: Authors' own analysis based on study material.

An additional regression analysis showed that the value of gross investments increases with the increase in savings possessed by small farms. The increase of savings by PLN 1 results in the increase of investments by PLN 0,13. This small increase in the value of gross investments in small agricultural holdings may suggest that these holdings are not able to reproduce their production potential. Investments made by them are not very innovative and are not aimed at strengthening agricultural holdings and their innovativeness, but only at improving work safety or modernizing their assets.

\subsection{Determinants of Savings of Small Farms}

In the initial model, the probability of generating higher savings by small farms in Poland considered all variables listed in Table 1. According to the adopted methodology, only those variables that have a significant impact on the variable $Y$ —the level of savings-were left in the model using the backward step regression method. The analysis of the results of estimating the parameters of the probability model of higher savings collection by small farms in Poland showed statistical significance of four variables: $X_{5}$-agricultural area; $X_{11}$-total liabilities; $X_{12}$-gross investment; $X_{13}$-gross value added. Empirical results obtained from the logit model estimation are presented in Table 6. The estimated final model defining socioeconomic factors influencing the probability of generating higher savings by small farms in Poland has the following form:

$$
p_{i}=\frac{e^{3.4671+1.0211 x_{5}-1.2184 x_{11}-0.9476+1.7548 x_{13}}}{1+e^{3.4671+1.0211 x_{5}-1.2184 x_{11}-0.9476 x_{12}+1.7548 x_{13}}}
$$


Table 6. Evaluation of logit model parameters.

\begin{tabular}{ccccc}
\hline \multirow{2}{*}{ Variable } & Variable Name & $\begin{array}{c}\text { Parameter } \\
\text { Evaluation }\end{array}$ & $p$-Value & Odds Ratio \\
\cline { 2 - 5 } & Constant & $\mathbf{3 . 4 6 7 1}$ & - & - \\
\hline$X_{5}$ & $\begin{array}{c}\text { utilized } \\
\text { agricultural area }\end{array}$ & 1.0211 & 0.0083 & 2.7764 \\
$X_{11}$ & total liabilities & -1.2184 & 0.0027 & 0.2956 \\
$X_{12}$ & gross investment & -0.9476 & 0.0083 & 0.3876 \\
$X_{13}$ & gross value added & 1.7548 & 0.00008 & 5.7827 \\
\hline
\end{tabular}

Source: Authors' own analysis based on study material.

The quality assessment of the model was based on the value of the coefficient $R^{2}$ count and the ROC curve (Figure 1). The results indicate that the classification based on the model is much better than random. The results of the Hosmer-Lemeshow test indicate that there are no significant differences between the empirical and theoretical numbers that result from the estimated logistic regression models.

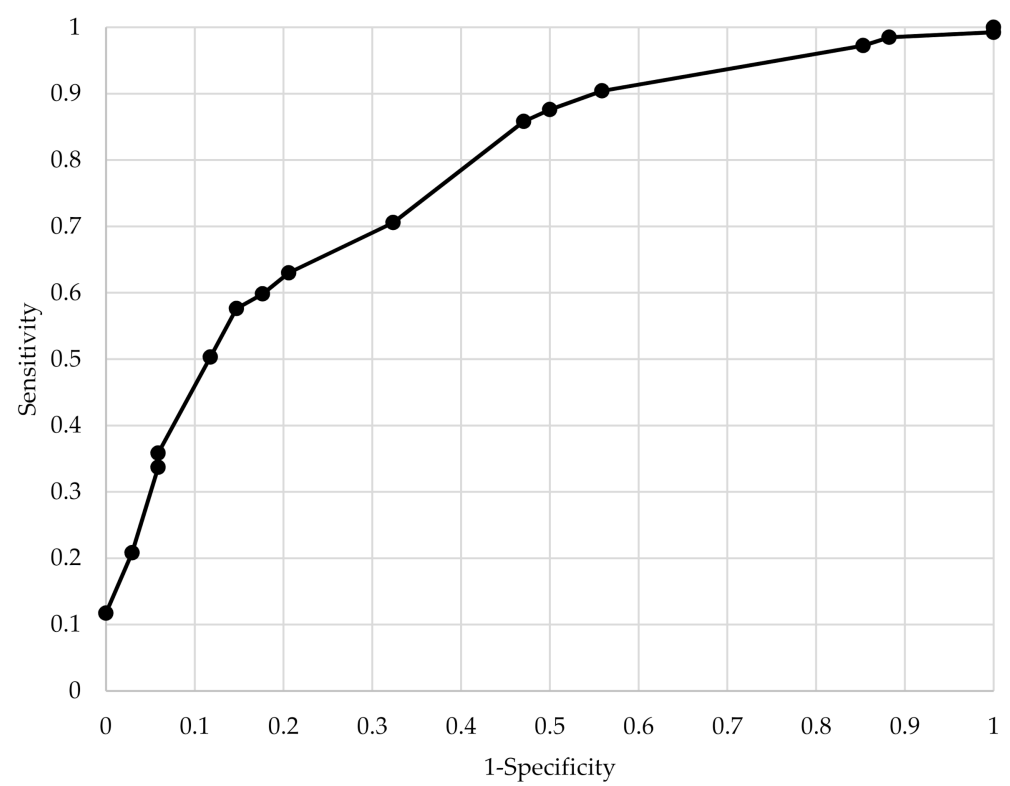

Figure 1. ROC curve for the model.

The area under the ROC curve is 0.78 and it is significantly greater than 0.5 (at a significance level greater than 0.000001).

The results suggest that in the model, a statistically positive influence of agricultural area $\left(X_{5}\right)$ and gross value added $\left(X_{13}\right)$ is observedon the dependent variable. This means that a larger area of agricultural land results in agreater probability of collecting higher savings by small farms. The survey results are consistent with those obtained by Rurangwa et al. [53], Chowa et al. [92], Odoh et al. [49], Kolandavel and Nigatu [60], Uhuegbulem et al. [54], and Tukela [52]. The area of an agricultural holding determines its development potential [93]. The increase in acreage translates into an increase in the scale of production, resulting in increased income and thus savings. Furthermore, having a larger area at their disposal, small farmers, apart from production for their own needs, carry out production thatis intended for sale, mainly direct sales. This may result in higher income and thus contribute to generating higher savings. If the other factors considered in the model remain unchanged, the chance of having higher savings will increase by $177 \%$ for agricultural areas above $7.22 \mathrm{ha}$. Statistically, a higher gross value added also had a positive impact on a higher level of savings mobilization. The chance for accumulating higher savings in small agricultural holdings in Poland will increase by $478 \%$ for farms 
with gross value added of above PLN 32,660 (EUR 8166). Gross value added is a key productivity category of agricultural activity. It illustrates the income situation of agricultural holdings [94]. With low income, the accumulation of capital from existing incomes is difficult. The accumulation of capital will depend on the amount of income and economic surpluses generated within the framework of agricultural activity, as well as the development of an individual demand curve for agricultural production factors. Various empirical studies based on different methods carried out in different parts of the world have shown a positive relationship between the level of income achieved and savings [95].

The following variables have a statistically significant negative impact on the dependent variable: total liabilities $\left(X_{11}\right)$ and gross investment value $\left(X_{12}\right)$. Therefore, having liabilities or a higher value of gross investment in the holding decreases the probability of savings accumulation. Using foreign capital to finance activities reduces the chance of collecting higher savings in small agricultural holdings by $71 \%$.

Having liabilities may involve the necessity to cover current expenses related to the costs of functioning of an agricultural holding or the implementation of investments in agricultural holdings. It can be expected that agricultural holdings with economic surpluses within agricultural activity have greater access to the financial market [96] and thus co-financing of economic activity, including investment activity financed with credits and loans. The cost of capital incurred in connection with a loan or credit is covered by the surplus generated by the agricultural activity, resulting in a reduction or even lack of savings [58,97], especially when a lower than expected return on investment is achieved.

The same applies to the increase in gross investment. If the value of gross investment in small farms increases above PLN 642 (EUR 160), the chance for accumulating higher savings will decrease by $62 \%$. Therefore, investment expenditures are negatively connected with maintaining savings. Although the negative sign is contrary to a priori expectations, it seems probable, as increasing investment requires greater financial outlays, which will more likely reduce the amount saved, especially in the short term [47]. Such a relationship enhances the borrowing capacity to make such outlays and undercuts the requirement of cash holding [98].

\section{Conclusions}

\subsection{Diversity}

Savings are an important aspect of the functioning of agricultural holdings, as they allow farmers to have a direct influence on the development and changes in their economic activity, as well as being a vital element of financial security in case of unforeseen events. This study provides evidence of the diversity of savings in small farms and the impact of several factors determining their level. In 2017, more than $97 \%$ of small individual farms in Poland were able to self-finance and generate savings from their core business. Although the size of savings generated by small farms may suggest the rather limited importance of savings in the cash flow of the analyzed farms, the social and economic roles of savings are essential. In Poland, but also in other countries, savings are important for strengthening the position of small farms and improving the quality of life of the farmer families. They thus contribute to the achievement of sustainable development. However, the limitations experienced by small farms resulting from low profitability and lack of ability to self-finance and generate savings will make it much more difficult for them to meet the expectations of becoming promoters of sustainable development [99]. As the demand for sustainable agriculture increases, small farmers are increasingly required to maintain access to global markets. The low savings of small farms generated by their operations are a demotivator for any future action. How can small farmers get involved in an ever-evolving sustainability process when they lack the resources to make the necessary investments?

There are large differences in the scale of generated savings among the studied farms. The study shows that more than one-half of small farms in Poland generate savings of PLN 25,849 (EUR 6462). The level of savings generated by small farmers is low. This level of savings creates not only potential 
problems related to long-term financial uncertainty, but also short-term concerns about households' ability to cover unexpected expenses related to their current needs [100]. With such a low accumulation of income, sustainable development in this group of farms will not be possible in the nearest future.

An in-depth study reveals that there is a visible variation in the level of savings generated, depending on age, education, or type of production. Middle-aged farmers and ones with higher education levels achieve a much higher level of savings than others.

The capacity of generating higher savings within the conducted agricultural activity in small farms depends on many social and economic factors, as evidenced by literature studies and empirical research carried out. Based on the conducted study, it can be concluded that the area size and gross value added reflecting the profitability of farms have a significant positive impact on generating savings by small farms. The chance for mobilization of savings by small farms in Poland increases by $177 \%$ with a larger area and by $478 \%$ with a higher gross value added. On the other hand, the amount of liabilities and the value of undertaken investments have a significant negative impact on the generation of savings in small agricultural holdings. An increase in liabilities or a higher value of gross investments reduces the chance for mobilization of savings by small agricultural holdings.

\subsection{Dilemmas}

There are several dilemmas concerning the possibility of increasing the generated savings in the studied farms and in small farms in Poland in general. Firstly, it would not be possible to increase the savings of small farms, and thus increase their role as promoters of sustainable development, without public support. It is not possible to make progress towards sustainability unless the economic resilience and well-being of farmers are improved first. Subsidies granted under the agricultural and rural development policy are a good start, but they must be supported by a range of institutional activities. These activities include, among others, the establishment and promotion of comprehensive advisory services on sustainable development, the improvement of farmers' education, and the improvement of university courses and other training programs [101]. In most of the analyzed agricultural holdings, farmers benefited from various measures aimed at increasing their profitability and improving their competitiveness. This should be positively assessed. Fast and successful development of small farms thanks to public support may motivate other farmers to take advantage of this support. Secondly, it is necessary to increase access of small farmers to preferential loans. Preferential credits and loans specifically targeted at small farmers will result, among other things, in investments in equipment or modern facilities which, in themselves, generate lower costs and allow significant savings. Thirdly, one of the most important challenges facing small farms is increasing their profitability. This dilemma is gaining in importance especially today when many countries are fighting the COVID-19 pandemic, an event that will have a huge impact on the economy. The period in which the pandemic appeared in Poland was the busiest one, especially in horticultural farms supplying fruit and vegetables to the market. The lockdown of the economy in many countries will have a negative impact on the sale of products and thus on incomes, which will translate into a limited capacity of generating savings, not only for small farms but also for medium and large ones. Reduced orders are not the only problem for small farms, especially those operating in horticulture. There are also problems related to production, especially the problem of the lack of an adequate number of workers. Most people working seasonally in agriculture are mainly from Ukraine. The pandemic has forced them to return to their home country. The closure of borders prevents them from returning to work. It can also be expected that because of the pandemic many people who lose their jobs outside agriculture will return to the countryside. Therefore, some of the savings owned by small farms maybe used for current consumption and not for investments. Another dilemma is that of mobilizing savings. Studies indicate that savings are increasing but expenditures related to gross investments in small farms are decreasing. These farms are not able to reproduce their production potential. For small farms, savings are accumulated due to transactional motives, i.e., they serve to satisfy consumption needs or they are maintained mainly due toprudential motives. Their small share is allocated to increase 
the value of farm assets. The analysis shows that the value of savings allocated to investments in small farms is negligible. On this basis, it can be suggested that investments in small farms are not very innovative and rarely aim at strengthening farms and innovation. Most of them will be aimed at improving work safety or modernizing basic infrastructure.

\subsection{Implications}

The results of the research enable formulating recommendations for future policy, which should support measures facilitating an increase in the profitability of small farms. The income generated by small farmers leads to the accumulation of a low level of savings, as shown by the research results. State policy in favor of small farmers should focus on enabling small farms to increase their acreage and supporting development (investment) activities mainly by increasing access to external financing. This would enable owners of small farms to increase the scale of production and to modernize or purchase fixed assets necessary to expand or diversify their activities. Support for small farms also means the reconstruction of the institution of a cooperative market for sale and direct sale of agri-food products and the liberalization of administrative and veterinary regulations and procedures [66]. It is also important to support advisory services, which can significantly increase education in the field of economic awareness, market and climate change, and investments, especially those of an innovative nature.

\subsection{Future}

Future studies should repeat existing ones to identify the factors that determine the possibilities of saving in small farms in terms of other factors not yet analyzed. This is important because of the high variability of conditions in which small farms operate and the forces and catalysts of these changes. It is worth analyzing how the COVID-19 pandemic has affected the size and mobilization of savings in small farms. It may turn out that small farms, due to their poor connection to the market, did not feel the economic effects of the pandemic significantly. Moreover, it seems useful to carry out a similar analysis which, instead of considering small farms, would focus on farms with different sizes of acreage or different types of farming. Finally, there is also a need for a more in-depth study of the impact of savings on farm sustainability, which is often a long-term outcome.

Author Contributions: Conceptualization, B.W. and A.K.-K.; methodology, A.S.-R.; software, A.S.-R.; validation, A.S.-R. and A.K.-K.; formal analysis, A.S.-R. and A.K.-K.; investigation, B.W. and A.K.-K.; resources, B.W.; data curation, B.W.; writing-original draft preparation, B.W. and A.K.-K.; writing—review and editing, B.W. and A.K.-K.; visualization, A.S.-R. and A.K.-K.; supervision, B.W., A.K.-K. and A.S.-R.; project administration, A.K.-K.; funding acquisition, B.W., A.K.-K. and A.S.-R. All authors have read and agreed to the published version of the manuscript.

Funding: This research received no external funding.

Conflicts of Interest: The authors declare no conflict of interest.

\section{References}

1. Kata, R.; Zajac, D. Rola banków spółdzielczych w finansowaniu zrównoważonego rozwoju gospodarki chłopskiej regionu podkarpackiego. (The role of cooperative banks in financing of sustainable development of peasant's economy of the Podkarpacie region). Ann. Polish Assoc. Agric. Agribus. Econ. 2000, 6, 118-123.

2. Nuhu, H.S.; Donye, A.O.; Bzugu, P.M.; Ani, A.O. The relationship between savings mobilization technique and livelihood activities of rural women in Borno State, Nigeria. Int. J. Acad. Res. Bus. Soc. Sci. 2015, 5, 479-496. [CrossRef]

3. Veveris, A.; Šapolaitè, V.; Raišienè, A.G.; Bilan, Y. How Rural Development Programmes Serve for Viability of Small Farms? Case of Latvia and Lithuania. AGRIS On-line Pap. Econ. Inform. 2019, 11, 103-113. [CrossRef]

4. Guiomar, N.; Godinho, S.; Pinto-Correia, T.; Almeida, M.; Bartolini, F.; Bezák, P.; Biró, M.; Bjørkhaug, H.; Bojnec, Š.; Brunori, G.; et al. Typology and distribution of small farms in Europe: Towards a better picture. Land Use Policy 2018, 75, 784-798. [CrossRef] 
5. Fairtrade International. Powering Up Smallholder Farmers to Make Food Fair: A Five Point Agenda. Available online: https://files.fairtrade.net/publications/2013_PoweringUpSmallholderFarmers.pdf (accessed on 1 May 2020).

6. Tudor, M.M. Small scale agriculture as a resilient system in rural Romania. Stud. Agric. Econ. 2015, 117, 27-34. [CrossRef]

7. Wojewodzic, T. Procesy Dywestycji i Dezagraryzacji na Obszarach o Rozdrobnionej Strukturze Agrarnej; Publisheing House of the University of Agriculture in Krakow: Krakow, Poland, 2017.

8. Mickiewicz, B.; Mickiewicz, A. Problematyka małych gospodarstw rolnych w rolnictwie polskim w latach 2014-2020 w świetle regulacji prawnych Parlamentu Europejskiego i Rady. (The issues of small agricultural farms in Polish agriculture in the years 2014-2020 in the light of legal regulations of the European Parliament and of the Council). Probl. Small Agric. Hold. 2016, 1, 33-44. [CrossRef]

9. Kiryluk-Dryjska, E.; Beba, P. The Potential for Development of Non-Agricultural Activities in Rural Areas of Northwest Poland. J. Agribus. Rural Dev. 2018, 2, 137-142. [CrossRef]

10. Michalska, S. Społeczny wymiar funkcjonowania drobnych gospodarstw rolnych. (Social aspects of the functioning of small farms). Probl. Small Agric. Hold. 2012, 1, 85-94.

11. Alexandri, C.; Luca, L. The role of small farms in Romania and their future in the face of challenges of the CAP post 2013. Probl. Small Agric. Hold. 2012, 1, 13-30.

12. Bukraba-Rylska, I. The role of small farms in creating capital and cultural heritage of the village. Probl. Small Agric. Hold. 2012, 1, 43-60.

13. Daugstad, K.; Rønningen, K.; Skar, B. Agriculture as an upholder of cultural heritage? Conceptualizations and value judgements-A Norwegian perspective in international context. J. Rural Study 2006, 22, 67-81. [CrossRef]

14. D'Souza, G.; Ikerd, J. Small Farms and Sustainable Development: Is Small More Sustainable? J. Agric. Appl. Econ. 1996, 28, 73-83. [CrossRef]

15. Thompson, E., Jr. Small Is Bountiful: The Importance of Small Farms in America; American Farmland Tiwst: Washington, DC, USA, 1986.

16. Boyce, J.K. A Future for Small Farms? Biodiversity and Agriculture; Working Paper Series 86; Political Economy Research Institute; The University of Massachusetts: Amherst, MA, USA, 2004.

17. Heidhues, F.; Brüntrup, M. Subsistence agriculture in development: Its role in processes of structural change. In Subsistence Agriculture in Central and Eastern Europe: How to Break a Vicious Cycle? Studies on the Agriculture and Food Sector in Central and Eastern Europe; Abele, S., Frohberg, K., Eds.; no. 22; IAMO: Halle, Germany, 2003.

18. Gioia, A. Small Farms in Europe: Time for a Re-definition. Available online: https://www.accesstoland.eu/ Small-farms-in-Europe-Time-for-a-redefinition (accessed on 20 May 2020).

19. Shucksmith, M.D.; Rønningen, K. The Uplands after neoliberalism? The role of the small farm in rural sustainability. J. Rural Stud. 2011, 27, 3275-3287. [CrossRef]

20. Borychowski, M.; Poczta-Wajda, A.; Sapa, A. Small farms in the world: Selected issues. In Small Farms in the Paradigm of Sustainable Development. Case Studies of Selected Central and Eastern European Countries; Stępien, S., Maican, S., Eds.; Wydawnictwo Adam Marszałek: Toruń, Poland, 2020.

21. Nwibo, S.U.; Nwakpu, C.; Eze, A.V. Income and Investment Portfolio of Smallholder Farmers in Ezza South Local Government Area of Ebonyi State, Nigeria. Eur. J. Sci. Res. 2017, 145, 328-335.

22. Narayanan, S.; Gulati, A. Globalization and the Smallholders: A Review of Issues, Approaches, and Implications; Markets and Structural Studies Division Discussion Paper No. 50; International Food Policy Research Institute: Washington, DC, USA, 2002.

23. Sarris, A.H.; Doucha, T.; Mathijs, E. Agricultural restructuring in Central and Eastern Europe: Implications for competitiveness and rural development. Eur. Rev. Agric. Econ. 1999, 26, 305-329. [CrossRef]

24. Musiał, W.; Drygas, M. Dylematy procesu delimitacji drobnych gospodarstw rolnych. (Dilemmas in the Process of Marking Boundries of Small Farms). Wieś Rol. 2013, 2, 55-74.

25. Knickel, K.; Zemeckis, R.; Tisenkopfs, T. A critical reflection of the meaning of agricultural modernization in a world of increasing demands and finite resources. In Rural Development 2013: Innovations and SustainabilityProceedings; ASU Publishing Center: Kaunas, Lithuania, 2013; pp. 561-567.

26. FAO; IFAD; WFP. The State of Food Insecurity in the World 2014-Strengthening the Enabling Environment to Improve Food Security and Nutrition; Food and Agriculture Organization of the UN: Rome, Italy, 2014. 
27. Harnowski, A.; Parzonko, A.; Kotyza, A.; Kondraszuk, T.; Bórawski, P.; Smutka, L. Factors determining the development of small farms in Central and Eastern Poland. Sustainability 2020, 12, 5095. [CrossRef]

28. Davidova, S.; Fredriksson, L.; Gorton, M.; Mishev, P.; Petrovici, D. Subsistence farming, incomes, and agricultural livelihoods in the new member states of the European Union. Environ. Plan. CGov. Policy 2012, 30, 209-227. [CrossRef]

29. Bożek, J. Differentiation and dynamics of number of small agricultural farms in European Union Countries. Probl. Small Agric. Hold. 2018, 3, 5-19. [CrossRef]

30. Gioia, A.; Rioufol, V. Small Farms in Europe: Viable but Underestimated. AIAB Lazio Regional wert AG The Real Farming Trust Rurbans Soil Association Terre de Liens. Available online: https://www.accesstoland.eu/ Small-farms-in-Europe-viable-but-underestimated (accessed on 5 July 2020).

31. Touhami, A.; Florence, A.; Najat, M.F.; Sabine, M. A Micro-econometric Analysis of Households Saving Determinants in Morocco. Afr. Rev. Money Financ. Bank. 2010, 1, 7-21.

32. Cronje, M. Creating A Savings Culture for the Black Middle Class in South Africa; Policy Guidelines and Lessons from China and India; University of Stellenbosch: Stellenbosch, South Africa, 2020; Available online: https://www.semanticscholar.org/paper/Creating-a-savings-culture-for-the-Black-middle-in-Cronje/ 01dc94cdccbe0ae806b84e57dfccca02b2ea03fa (accessed on 18 May 2020).

33. Nga, M. An Investigative Analysis into the Saving Behaviour of Poor Households in Developing Countries: With Specific Reference to South Africa. Research Report prepared in partial fulfillment of the requirement for the degree of master's in economics. Available online: http://etd.uwc.ac.za/xmlui/handle/11394/2081 (accessed on 5 May 2020).

34. Soumaya, H. The Effect of Debt, Firm Size and Liquidity on Investment-Cash Flow Sensitivity. Int. J. Account. Financ. Report. 2012, 2, 1-16. [CrossRef]

35. Karlan, D.; Ratan, A.; Zinman, J. Savings by and for the Poor: A Research Review and Agenda; Center for Global Development: Washington, DC, USA, 2020; Available online: https://www.cgdev.org/publication/savingsand-poorresearch-review-and-agenda-working-paper-346 (accessed on 5 July 2020).

36. Gokhale, J. Are We Saving Enough? Economic Commentary, Cleveland: Federal Reserve Bank of Cleveland. Available online: https:/www.clevelandfed.org/en/newsroom-and-events/publications/ economic-commentary/economic-commentary-archives/2000-economic-commentaries/ec-20000701-arewe-saving-enough.aspx (accessed on 5 July 2020).

37. Sibomana, J.P.; Shukla, J. Effect of village savings and loan associations on small and medium enterprise (SME) growth in Rwanda: Survey of Kayonzadistrict. Int. J. Bus. Manag. Rev. 2016, 4, 57-79.

38. Gruszewska, E. Instytucje A Proces Tworzenia Kapitatu w Polsce; Uniwersytet w Białymstoku: Białystok, Poland, 2013.

39. Mkpado, M.; Arene, C.J. Does group design affect savings mobilization of rural Agricultural micro credit groups? Evidence from Nigeria. Econ. Aff. 2010, 55, 231-242.

40. Ksoll, C.; Lilleør, H.B.; Lønborg, J.H.; Rasmussen, O.D. Impact of Village Savings and Loan Associations: Evidence from a cluster randomized trial. J. Dev. Econ. 2016, 120, 70-85. [CrossRef]

41. Syed, S.; Miyazako, M. Promoting investment in agriculture for increased production and productivity. FAO 2013. Available online: http://www.fao.org/3/a-az725e.pdf (accessed on 5 May 2020).

42. Zeller, M.; Sharma, M. Many borrow, more save and all insure: Implications for food and micro-finance policy. Food Policy 2000, 25, 143-167. [CrossRef]

43. Ajah, E.A.; Itam, K.O.; Elemi, G.F.; Eniang, S.V. Determinants of savings in Calabar Agricultural Zone of Cross River State, Nigeria. J. Econ. Financ. 2017, 8, 45-54.

44. Bartle, P. Savings Mobilization. Available online: http://www.scn.org/ip/cds (accessed on 1 July 2020).

45. Despard, M.R.; Friedline, T.; Martin-West, S. Why do households lack emergency savings? The role of financial capability. J. Fam. Econ. Issues 2020, 41, 542-557. [CrossRef]

46. Bime, M.J.; Mbanasor, J. Determinants of informal savings amongst vegetable farmers in North West Region, Cameroon. J. Dev. Agric. Econ. 2011, 3, 588-592.

47. Aidoo-Mensah, D. Determinants of rural household savings behaviour: The case of tomato farmers in Ghana. Rev. Agric. Appl. Econ. 2019, 22, 55-70. [CrossRef]

48. Adeyemo, R.A.; Bamire, A.S. Saving and Investment Patterns of Cooperatives Farmers in Southwestern Nigeria. J. Soc. Sci. 2005, 11, 183-192. [CrossRef]

49. Odoh, N.Z.; Nwibo, S.U.; Eze, A.V.; Igwe, E.O. Farmers income and savings pattern in Benue State, Nigeria. J. Agric. Ext. 2020, 24, 128-137. [CrossRef] 
50. Obayelu, O.A. Determinants of Savings Rate in Rural Nigeria: A Micro Study of Kwara State. J. Adv. Dev. Econ. 2013, 2, 1-14. [CrossRef]

51. Obalola, T.O.; Audu, R.O.; Danilola, S.T. Determinants of savings among smallholder farmers in Sokoto South Local Government Area, Sokoko State, Nigeria. Acta Agric. Slov. 2018, 111, 341-347. [CrossRef]

52. Tukela, B. Determinants of savings behavior among rural households in case of BorichaWoreda, Sidama Zone, Southern Ethiopia. Int. J. Recent Sci. Res. 2018, 9, 29748-29752. [CrossRef]

53. Rurangwa, E.; Mburu, D.M.; Mulyungi, P.; Eric, N.; Nsengiyumva, A. Factors affecting savings of small cale coffee farmers in Rwanda. Int. J. Innov. Res. Sci. Eng. Technol. 2018, 7, 1285-1290.

54. Uhuegbulem, I.J.; Henri-Ukoha, A.; Osuji, M.N.; Ukoha, I.I.; Oshaji, I.O. Determinants of savings among small-scale food crop farmers in Owerri West Local Government Area of Imo State, Nigeria. J. Agric. Soc. Res. 2016, 16, 16-24.

55. Kibet, L.K.; Muntai, B.K.; Ouma, D.E.; Ouma, S.A.; Owour, G. Determinants of household saving: Case study of smallholder farmers, entrepreneurs, and teachers in rural Kenya. J. Dev. Agric. Econ. 2009, 1, 137-143.

56. Pailwar, V.K.; Kaur, J.; Saxena, K.; Nijhara, M. Impact of membership of financial Institutions on rural saving: A micro-level study. Int. Bus. Res. J. 2010, 9, 139-148. [CrossRef]

57. Fisher, P.J. Black-white differences in saving behaviors. Financ. Serv. Rev. 2010, 19, 1-16.

58. Hardin, W.G.; Highfield, M.J.; Hill, M.D.; Kelly, W. The determinants of REIT cash holdings. J. Real Estate Financ. Econ. 2009, 39, 39-57. [CrossRef]

59. Osondu, C.K.; Obike, K.C.; Ogbonna, S.I. Savings, income and investment patterns and its determinants among small holder arable crop farmers in Umuahia Capital Territory, Abia State Nigeria. Eur. J. Bus. Innov. Res. 2015, 3, 51-70.

60. Kolandavel, N.; Nigatu, A.A. Determinants of cash-savings of farmers in rural savings and credit cooperatives in Southern Ethiopia. Asian Res. J. Agric. 2017, 4, 1-11. [CrossRef]

61. Feye, D.A. Determinants of rural households' savings: Smallholder farmers level analysis in case of Baleegasgaar District, Oromia, Ethiopia. Int. J. Res. Eng. Manag. 2020, 3, 32-45.

62. Nayak, S. Determinants and Pattern of Saving Behavior in Rural Households of Western Odisha. Master's Thesis in Development Studies, National Institute of Technology, Ajitgarh, India, 2013.

63. Ahmad, M.; Asghar, T. Estimation of Saving Behavior in Pakistan Using Micro data. Lahore J. Econ. 2004, 9, 73-85. [CrossRef]

64. Girma, T.; Belay, K.; Bezabih, E.; Jema, H. Determinants of rural household savings in Ethiopia:Thecase of East Hararghe zone, Oromia regional state. J. Econ.Sustain. Dev. 2013, 4, 66-75.

65. Gedela, S.P.R. Determinants of saving behaviour in rural and tribal households (An empirical analysis of Visakhapatnam District). Int. J. Res.Soc. Sci. 2012, 2, 108-128.

66. Gruchelski, M.; Niemczyk, J. Małe gospodarstwa rolne w Polsce a paradygmat rozwoju zrównoważonego (Small farms in Poland and the paradigm of sustainable development). PostępTech. Przetwórstwa Spożywczego 2016, 2, 134-140.

67. Okularczyk, S. Profitability Trends in Pig Production in 1991-2003. Ann. Anim. Sci. 2004, 4, 197-203.

68. Strzelecka, A.; Kurdyś-Kujawska, A.; Zawadzka, D. What Determines the Profitability of Agricultural Production? Reflections on the Example of Farms in Poland. Entrep. Manag. 2018, 19, 349-362.

69. Mishra, A.K.; El-Osta, H.S.; Steele, C.J. Factors Affecting the Profitability of Limited Resource and Other Small Farms. Agric. Financ. Rev. 1999, 59, 77-99.

70. Munćan, P.; Todorović, S.; Munćan, M. Profitability of Family Farms Directed at Crop Production. Econ. Agric. 2014, 61, 1-11. [CrossRef]

71. Natukunda, K.; Kugonza, D.R.; Kyarisiima, C.C. Indigenous Chickens of the Kamuli Plains in Uganda: II Factors Affecting their Marketing and Profitability. Livest. Res. Rural Dev. 2011, 23, 221. Available online: http://www.lrrd.org/lrrd23/10/natu23221.htm (accessed on 5 May 2020).

72. Frątczak, E. Zaawansowane Metody Analiz Statystycznych; SGH: Warszawa, Poland, 2012.

73. Kurdyś-Kujawska, A.; Sompolska-Rzechuła, A. Determinants of farmers demand for subsidized agricultural insurance in Poland. In Proceedings of the 2018 International Conference Economic Science for Rural Development 2018, Jelgava, Latvia, 9-11 May 2018. no. 47. [CrossRef]

74. Michler, J.D.; Josephson, A.L. To specialize or diversify: Agricultural diversity and poverty dynamics in Ethiopia. World Dev. 2017, 89, 214-226. [CrossRef] 
75. Kurdyś-Kujawska, A.; Zawadzka, D.; Sompolska-Rzechuła, A. The probability of farm's diversification-on the example of Central Pomerania in Poland. Bulg. J. Agric. Sci. 2018, 24, 171-179.

76. McCord, P.F.; Cox, M.; Schmitt-Harsh, M.; Evans, T.P. Crop Diversification as a Smallholder Livelihood Strategy within Semi-Arid Agricultural Systems near Mount Kenya. Land Use Policy 2015, 42, 738-750. [CrossRef]

77. Asante, B.; Villano, R.; Patrick, I.; Battese, G. Determinants of farms diversification in integrated crop-livestock farming systems in Ghana. Renew. Agric. Food Syst. 2018, 33, 131-149. [CrossRef]

78. Bommarco, R.; Kleijn, D.; Potts, S.G. Ecological intensification: Harnessing ecosystem services for food security. Trends Ecol. Evol. 2013, 28, 230-238. [CrossRef]

79. Kawa, N.C.; Clavijo, M.J.A.; Clement, C.R. Household Agrobiodiversity Management on Amazonian Dark Earths, Oxisols, and Floodplain Soils on the Lower Madeira River. Braz. Hum. Ecol. 2015, 43, 339-353. [CrossRef]

80. Acharya, S.P.; Basavaraja, H.; Kunnal, L.B.; Mahajanashetti, S.B.; Bhat, A.R.S. Crop Diversification in Karnataka: An Economic Analysis. Agric. Econ. Res. Rev. 2011, 24, 351-357. [CrossRef]

81. Bellon, M.R.; Kotu, B.H.; Azzarri, C.; Caracciolo, F. To diversify or not to diversify, that is the question. Pursuing agricultural development for smallholder farmers in marginal areas of Ghana. World Dev. 2020, 125, 104682. [CrossRef]

82. Lin, B.B. Resilience in Agriculture through Crop Diversification: Adaptive Management for Environmental Change. BioScience 2011, 61, 183-193. [CrossRef]

83. Anang, B.T.; Dawuda, I.; Imoro, L. Determinants of savings habit among Clients of Bonzali rural bank in the Tolon-Kumbungu District of Ghana. UDS Int. J. Dev. 2015, 2, 86-95.

84. Xiao, J.J.; Fan, J.X. A comparison of saving motives of urban Chinese and American workers. Fam. Consum. Sci. Res. J. 2002, 30, 463-495. [CrossRef]

85. Aidoo-Mensah, D. Comparative Analysis of Savers and Non-Savers among Tomato Farmers in Ghana. Agric. Trop. Subtrop. 2017, 50, 175-189. [CrossRef]

86. Lidi, B.Y.; Bedemo, A.; Belina, M. Determinants of saving behavior of farm households in rural Ethiopia: The Double Hurdle Approach. Dev. Ctry. Stud. 2017, 7, 17-26.

87. Walls, H.L.; Johnston, D.; Tak, M.; Dixon, J.; Hanefeld, J.; Hull, E.; Smith, R.D. The impact of agricultural input subsidies on food and nutrition security: A systematic review. Food Secur. 2018, 10, 1425-1436. [CrossRef]

88. Wieliczko, B.; Sompolska-Rzechuła, A.; Kurdyś-Kujawska, A. Determinants of the Use of Subsidies for the Development of Rural Areas by Small Agricultural Holdings: Case of Poland. In Proceedings of the 2019 International Conference Economic Science For Rural Development, Jelgava, Latvia, 9-10 May 2019. no 50. [CrossRef]

89. Dwyer, J. Rural development under the CAP: Significance, likely impacts and modelling issues. Presented at the JRC Workshop. Ispra, Italy; 27 September 2005.

90. Copus, A.; Psaltopoulos, D.; Skuras, D.; Terluin, I.; Weingarten, P. Common Features of Diverse European Rural Areas: Review of Approaches to Rural Typolog; Final Report Version 1.4; Directorate General, IPTS-JRC, European Commission: Brussels, Belgium, 2007.

91. Ciaian, P.; Kancs, D.A.; Paloma, S.G.Y. Income distributional effects of CAP subsidies: Micro evidence from the EU. Outlook Agric. 2015, 44, 19-28. [CrossRef]

92. Chowa, G.A.; Masa, R.D.; Ansong, D. Determinants of saving among low-income individuals in rural Uganda: Evidence from assets Africa. Adv. Appl. Sociol. 2012, 2, 280-291. [CrossRef]

93. Prus, P. Farmers' opinions about the prospects of family farming development in Poland. In Proceedings of the 2018 International Conference Economic Science for Rural Development, Jelgava, Latvia, 9-11 May 2018. no 47. [CrossRef]

94. Poczta, W.; Fabisiak, A. Income Situation of Agriculture in the CEE-4 Countries. In Problems of World Agriculture. Polish Agriculture and Food Economy within the European Union; Szoege, H.M., Tyner, W.E., Eds.; RFS: Warsaw, Poland, 2006.

95. Fraczek, B. The factors affecting the level of household savings and their influence on economy development. In Proceedings of the 8th International Scientific Conference Financial Management of Firms and Financial Institutions Ostrava VŠB-TU Ostrava, Faculty of Economics, Finance Department, Ostrava, Czech Republic, 6-7 September 2011. 
96. Nwibo, S.U.; Mbam, B.N. Determinants of savings and investment capacities of farming households in Udi Local Goverment Area of Enugu State, Nigeria. Res. J. Financ. Account. 2013, 4, 59-69.

97. Singh, K.; Misra, M. Financial determinants of cash holding levels: An analysis of Indian agricultural enter prises. Agric. Econ. Czech 2019, 65, 240-248. [CrossRef]

98. Riddick, L.A.; Whited, T.M. The corporate propensity to save. J. Financ. 2009, 64, 1729-1766. [CrossRef]

99. Terlau, W.; Hirsch, D.; Blanke, M. Smallholder farmers as a backbone for the implementation of the Sustainable Development Goals. Sustain. Dev. 2019, 27, 523-529. [CrossRef]

100. Babiarz, R.; Robb, C. Financial literacy, and emergency savings. J. Fam. Econ. Issues 2014, 35, 40-50. [CrossRef]

101. Siebrecht, T. Sustainable agriculture and its implementation Gap-Overcoming obstacles to implementation. Sustainability 2020, 12, 3853. [CrossRef]

Publisher's Note: MDPI stays neutral with regard to jurisdictional claims in published maps and institutional affiliations.

(C) 2020 by the authors. Licensee MDPI, Basel, Switzerland. This article is an open access article distributed under the terms and conditions of the Creative Commons Attribution (CC BY) license (http://creativecommons.org/licenses/by/4.0/). 